\title{
Cytosolic Phospholipase A2 Group IV
}

National Cancer Institute

\section{Source}

National Cancer Institute. Cytosolic Phospholipase A2 Group IV. NCI Thesaurus. Code C19836.

A family of cytosolic enzymes that are involved in the calcium-dependent hydrolysis of phospholipids. 